\title{
PENGOLAHAN SAMPAH ORGANIK SEBAGAI SOLUSI EKONOMI DARI PERGURUAN TINGGI DI MASA PANDEMI
}

\author{
Shubhi Mahmashony Harimurti ${ }^{1,2}$, Eka Dewi Rahayu ${ }^{1}$, Yebi Yuriandala ${ }^{1,3}$, Adha Faiqol Aqli ${ }^{1}$, \\ Ghani Asrofi Sunandar ${ }^{1}$, Dion Rafiedhia Danistra ${ }^{1}$, Alfian Athal Rizky Pamungkas ${ }^{1}$, Deni \\ Sutiana ${ }^{1}$, Merina Indah Sari ${ }^{1}$ \\ ${ }^{1}$ Universitas Islam Indonesia

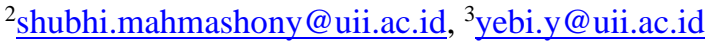

\begin{abstract}
Abstrak
Pandemi Corona Virus Disease 2019 (Covid-19) yang terjadi sejak awal tahun 2020 memaksa seluruh pekerjaan dilaksanakan dari rumah atau biasa dikenal dengan istilah Work From Home (WfH). Salah satu efek kegiatan WfH adalah meningkatnya timbulan sampah organik di rumah, di mana aktivitas yang biasanya di tempat kerja berpindah ke rumah atau tempat tinggal masing-masing. Sampah organik yang sebagian besar berupa sisa makanan bisa dikelola dan dimanfaatkan oleh masyarakat pada tingkat Rumah Tangga yaitu dengan cara pengomposan menggunakan komposter. Universitas Islam Indonesia melalui Kuliah Kerja Nyata (KKN) Pembelajaran Pemberdayaan Masyarakat (PPM) melaksanakan pengabdian masyarakat pengolahan sampah organik di Desa Ringinputih, Kecamatan Karangdowo, Kabupaten Klaten, Provinsi Jawa Tengah yang bertujuan untuk memberikan edukasi kepada masyarakat untuk mengelola sampah yang dihasilkan dari rumah tangga. Metode pelaksanaan pengabdian dengan model blended (campuran) yaitu dalam jaringan (daring) dan luar jaringan (luring). Media daring yang digunakan adalah Zoom Video Conference dan YouTube sedangkan luring dengan datang langsung ke Desa Ringinputih menggunakan protokol Kesehatan. Hasil dari kegiatan ini berupa cara pengolahan dan pemanfaatan sampah organik di rumah tangga oleh masyarakat Desa Ringinputih menjadi kompos. Selain itu, kompos yang dihasilkan harapannya dapat digunakan oleh masyarakat sebagai media tanam sayuran di rumah, sehingga masyarakat bisa mengkonsumsi sayuran organik yang ditanam sendiri.
\end{abstract}

Kata Kunci : KKN PPM, Sampah Organik, Pengomposan, Kompos.

\section{PENDAHULUAN}

Pandemi Corona Virus Disease 2019 (Covid-19) yang terjadi sejak awal tahun 2020 memaksa seluruh pekerjaan dilaksanakan dari rumah atau biasa dikenal dengan istilah Work From Home (WfH). Salah satu efek kegiatan WfH adalah meningkatnya timbulan sampah organik di rumah, di mana aktivitas yang biasanya di tempat kerja berpindah ke rumah atau tempat tinggal masingmasing. Sampah organik yang sebagian besar berupa sisa makanan bisa dikelola dan dimanfaatkan oleh masyarakat pada tingkat Rumah Tangga yaitu dengan cara pengomposan menggunakan komposter. Metode pengomposan yang banyak digunakan adalah pengomposan aerobik karena membutuhkan

$$
\text { Lingkungan Hidup dan Bencana }
$$


waktu yang lebih cepat, tidak berbau, dapat membunuh telur cacing dan bakteri pathogen karena temperatur yang tinggi pada proses pembuatannya sehingga kompos yang akan dihasilkan higienis (Damanhuri \& Padmi, 2010)

Universitas Islam Indonesia melalui Kuliah Kerja Nyata (KKN) Pembelajaran Pemberdayaan Masyarakat (PPM) melaksanakan pengabdian masyarakat pengolahan sampah organik di Desa Karangdowo. Program ini dipilih dilaksanakan karena belum efektifnya pengelolaan sampah organic di Desa tersebut yaitu sampah organik masih tercampur dengan non-organik. Selain itu pengelolaan sampah juga masih terbilang kurang dikarenakan biasanya hanya dikubur atau dibakar saja. Pengelolaan sampah yang seperti ini dapat menyebabkan pencemaran lingkungan. Jika secara jangka panjang terus dibiarkan maka akan menimbulkan penyakit-penyakit yang membahayakan generasi muda. Padahal sampahsampah tersebut memiliki nilai jika dikelola dengan baik, sehingga bisa meningkatkan kesehatan, kebersihan, bahkan income masyarakat serta mengurangi kemubadziran. Atas dasar hal ini maka tim pengabdian masyarakat memfokuskan untuk memberikan pengertian terkait komoditas sampah dan cara mengelolanya agar memberikan manfaat bagi masyarakat. Berdasarkan hal itu maka perlu pengelolaan komoditas sampah dengan baik dan benar. Program ini mengidentifikasi dari kasus yang sering terjadi yaitu kurangnya kesadaran dan pengetahuan masyarkat dalam menjaga dan mengolah sampah secara baik dan benar.

Kasus dari kebersihan lingkungan setiap tahunnya mengalami peningkatan yang cukup pesat. Hal ini disebabkan oleh kurangnya kesadaran serta pengetahuan masyarakat dalam mengolah sampah dan menjaga kebersihan lingkungan. Tempat sampah ataupun kotoran tidak dipergunakan dan dirawat dengan sebaik mungkin. Hal ini mengakibatkan lingkungan tidak sedap dipandang karena banyaknya sampah yang berhamburan, menimbulkan bau, dan akan memberikan dampak bagi kesehatan diantaranya yaitu penyakit diare, gangguan pernapasan, dan kulit. Oleh karena itu dengan adanya program kerja ini bertujuan untuk mengubah kebiasaan masyarakar untuk lebih baik lagi dalam menjaga kebersihan lingkungan sehingga nyaman, bersih, sejuk, dan sehat. Adapun program ini dilakukan untuk saling mengingatkan satu sama lain pentingnya menjaga kebersihan lingkungan agar memberikan kenyamanan dalam beraktifitas,

Program dilakukan setelah mengidentifikasi dari kasus yang sering terjadi yaitu kurangnya kesadaran dan pengetahuan masyarakat dalam menjaga dan mengolah sampah secara baik dan benar. Tim KKN PPM memberikan suatu penjelasan ataupun sosialisasi ke masyarakat. Sosialisasi ini berupa penyampaian materi kebersihan lingkungan berdasarkan sisi hukum yang ada di Indonesia untuk meningkatkan pemahaman masyarakat menjaga kebersihan lingkungan dan mengetahui dasar hukum yang ada di Indonesia tentang lingkungan hidup. Setelah dilakukan sosialisasi maka ada testimoni dari salah satu masyarakat untuk mengetahui ketercapaian dalam memahami materi yang disampaikan oleh mahasiswa KKN. Dengan sosialisasi ini harapannya kasus yang ada dapat teratasi sehingga dapat menciptakan beberapa manfaat terutama di bidang ekonomi.

Dalam kebersihan lingkungan, penting untuk menjaga, meningkatkan, dan mengingatkan satu sama lain arti pentingnya kesehatan lingkungan. Kebersihan adalah keadaan yang bersih yang terbebas dari kotoran seperti sampah, bau, dan sampah. Hasil penelitian Louis Pasteur mengatakan penyakit dapat ditularkan dengan adanya mikroba, zat kimia, virus, bakteri pathogen.(Wijayanti and Widyastari, 2018). Maka dari itu masyarakat harus peduli dalam menjaga kebersihan diri dan lingkungan agar terhindar dari penyakit dan terciptanya lingkungan yang nyaman, sejuk, bersih, dan sehat. Kebersihan lingkungan adalah cerminan dari budaya Indonesia yang selalu mengedepankan rasa kenyamanan sehingga dapat memberikan rasa kenyamanan bagi seseorang yang melakukakan aktivitas (Iskandar, 2018).

Dalam program ini permasalahan yang diangkat sering terjadi yaitu membuang sampah sembarangan, kurangnya kesadaran dalam menjaga lingkungan, dan mengolah sampah. Dari program ini saling mengigatkan satu sama lain untuk membuang sampah pada tempatnya dan menjelaskan manfaat 
menjaga kebersihan, memberi tahu bahwa sampah itu dapat dikelola dengan baik dan menghasilkan beberapa manfaat diantaranya yaitu dapat dijadikan taplak meja, dompet, tas, dan pupuk kompos. Harapan setelah masyarakat mengetahui manfaat dari sampah ini sehingga dapat meningkatkan rasa kepedulian dalam menjaga kebersihan lingkungan. Sampah juga akan memberikan nilai ekonomis bagi masyarakat sehingga dapat meningkatkan perekonomian terutama di masa pandemi Covid-19.

Pemanfaatan sampah organik masih belum banyak dilakukan terlebih lagi mengurangi penumpukan sampah dan menjadi produk pupuk organik dengan nilai komersial. Adapun tujuan dari kegiatan ini untuk menciptakan lingkungan yang sehat dan memberikan dampak dalam meningkatan perekonomian masyarakat.

\section{METODE}

Pengabdian masyarakat diselenggarakan dengan skema KKN PPM yang melibatkan sebanyak 28 mahasiswa dari program studi yang berbeda-beda. Mereka terbagi dalam tiga unit dan menjalankan program sesuai dengan tema yang ada. Dikarenakan kondisi darurat Covid-19 maka KKN PPM dilaksanakan secara campuran antara luring dan daring. Untuk kegiatan daring, selain memanfaatkan Zoom Meeting juga menggunakan tayangan YouTube baik berupa rekaman kegiatan sinkron yang diunggah dalam saluran 'KKN Ringinputih' maupun video yang khusus diproduksi sebanyak 9 buah. Rinciannya adalah tiga tentang media pembelajaran bagi siswa sekolah, 3 mengenai pemberdayaan masyarakat, dan sisanya dakwah. Semua video asinkron tersebut tetap mengacu pada tema besar yaitu pengolahan sampah organik sebagai solusi ekonomi di masa pandemi. Pelaksanaan kegiatan dimulai dengan sosialisasi online, penyuluhan, implementasi, analisis, dan evaluasi.

Sosialisasi kegiatan dilakukan melalui sistem online dengan sasaran warga Desa Ringinputih. Sosialisasi diberikan kepada masyarakat umum, perangkat dan pejabat desa, anggota PKK, anggota karang taruna, pelaku usaha, serta para pemilik ternak. Melalui media zoom meeting sosialisasi dilakukan secara kontinue kepada sasaran program. Pada tahapan sosialisasi pengolahan sampah organik ini juga tergambar antusiasme warga Desa Ringinputih dengan banyaknya pertanyaan yang dilontarkan.

Setelah sosialisasi selesai dilaksanakan pada tahapan selanjutnya dilakukan penyuluhan tentang pengelolaan sampah organik. Sampah organik yang dimaksud dalam hal ini terutama adalah sampah sisa makanan rumahtangga dan limbah hasil ternak yang secara umum belum terkelola dengan baik. Penyuluhan dilakukan dengan terjun langsung ke lokasi berbekal protokol kesehatan yang semestinya. Penyuluhan diberikan kepada masyarakat terutama warga pemilik ternak dengan langsung mengunjungi kandang-kandang ternak yang dimiliki warga. Di kandang ternak warga didampingi oleh pemiliknya, penyuluhan tata cara pengolahan limbah dilakukan. Limbah kotoran ternak yang ada di sebagian besar kandang masih belum terkelola dengan baik dan masih dibiarkan. Sehingga berpotensi menimbulkan pencemaran lingkungan dan mendatangkan banyak penyakit.

Selain penyuluhan tentang limbah ternak, dilaksanakan juga penyuluhan tentang pengelolaan sampah rumahtangga terutama sisa-sisa makanan yang banyak dihasilkan. Penyuluhan ini dilakukan secara langsung dengan melibatkan warga menggunakan alat komposter sederhana. Sebab tujuan pengelolaan limbah sisa makanan rumahtangga ini difokuskan menjadi pupuk kompos cair yang berguna untuk menyuburkan tanaman. Pembuatan pupuk kompos cair yang berasal dari limbah makanan rumahtangga dipilih karena cara pembuatanya yang sederhana dan tidak membutuhkan waktu yang lama sehingga sangat mudah dilakukan.

Pengelolaan limbah organik baik limbah makanan sisa rumahtangga maupun limbah kotoran ternak sangat bermanfaat bagi warga. Setelah dilakukan sosialisasi dan penyuluhan warga mampu mempraktekan secara mandiri berbekal pengetahuan yang didapatkan. Mulai dari ibu-ibu dengan sampah sisa makanan di rumah maupun para warga pemilik ternak yang sangat merasakan manfaat dari pengelolaan limbah. Sehingga limbah yang dulunya hanya dibuang dan dibiarkan begitu saja dengan tanpa pengolahan sekarang sudah bisa dijadikan sesuatu yang bermanfaat.

$$
\text { Lingkungan Hidup dan Bencana }
$$




\section{HASIL DAN PEMBAHASAN}

KKN yang dilaksanakan secara daring adalah keputusan dari Universitas Islam Indonesia yang berbeda dengan tahun sebelumnya. Hal tersebut, dikarenakan adanya wabah Covid-19 yang dialami oleh Negara Indonesia. Luaran yang diperoleh dari bidang pemberdayaan ini adalah video online yang ditujukan kepada warga Desa Ringinputih, Kecamatan Karangdowo, Kabupaten Klaten khususnya dan masyarakat Indonesia pada umumnya. Tema yang dijelaskan kepada warga yaitu tentang pengolahan sampah organik sisa makanan dan limbah kotaran sapi. Hal ini bertujuan untuk menambah nilai perekonomian warga khususnya yang memelihara sapi.

Sampah organik adalah sampah yang dihasilkan dari bahan-bahan hayati atau sisa dari makhluk hidup (alam) yang dapat diuraikan oleh mikroorganisme sehingga biasa disebut biodegradable. Sampah jenis ini biasanya berupa sayuran, buah-buahan, sisa makanan serta dedaunan baik yang kering atau yang mudah busuk (abduh, 2018). Pemanfaatan Sampah organik berupa sisa makanan dan limbah kotoran sapi masih belum banyak dilakukan di lokasi pengabdian, terlebih lagi mengurangi penumpukan sampah dan menjadi produk pupuk organik dengan nilai komersial. Adapun tujuan dari kegiatan ini untuk menciptakan lingkungan yang sehat dan memberikan dampak dalam meningkatan perekonomian masyarakat Metode pelaksanaan kegiatan dimulai dengan online, sosialisai, implementasi, analisis dan evaluasi, serta peningkatan.

Pengamatan dilakukan untuk meninjau area pemilik peternak sapi di yang selanjutnya ditemukan masalah baru dengan adanya kotoran hewan menyusui tersebut tidak terolah yang menimbulkan pencemaran lingkungan, bau, dan limbah yang menumpuk akan memakan banyak tempat untuk penyimpanan. Dari kegiatan ini dihasilkan teori dan materi guna untuk pengolahan limbah kotoran sapi serta alat komposter sebagai perangkat untuk mengelola sampah organik, melalui proses pengomposan. Selain itu, juga diperoleh nilai tambah dalam aspek ekonomi maupun kesehatan karena hilangnya polusi dari kotoran sapi dan sampah organik.

Salah satu pengolahan yang banyak digunakan untuk sampah organik adalah dengan membuat pupuk organik dengan cara pengomposan. Pembuatan kompos merupakan salah satu upaya alternatif dalam rangka mengolah sampah guna mengurangi timbulan sampah yang ada di lingkungan masyarakat. Selain itu, tidak menutup kemungkinan pengomposan dapat dijadikan sebagai sumber pendapatan sampingan. Pembuatan kompos dapat dilakukan oleh siapa saja, di mana saja dan dengan berbagai macam cara dari yang mudah hingga yang rumit. Pengomposan yang dilakukan dapat membantu program pemerintah dalam upaya pengurangan sampah dari sumber sehingga dapat menghasilkan lingkungan yang bersih dan terawat (Suryati, 2014). Kompos berasal dari sampah yang dihasilkan dari rumah tangga, pertanian dan peternakan yang mempunyai kandungan nitrogen, kalium, dan serat tinggi. Hewan ternak dapat mengeluarkan kotoran dalam jumlah banyak sebagai hasil dari limbah.

Berdasarkan penelitian Mulyatun (2016) menyatakan bahwa jumlah kotoran yang dikeluarkan pada ternak sapi setiap harinya berkisar $12 \%$ dari berat tubuhnya, maka jika kotoran tersebut tidak dekelola dengan baik akan berubah menjadi limbah yang banyak dan bisa tidak terkontrol, sehingga dapat menyebabkan pencemaran pada lingkungan, karena kotoran hewan ternak mengandung $\mathrm{NH}$ dan $\mathrm{NH}_{3} \quad$ Limbah kotoran sapi merupakan sampah peternakan yang paling diminati karena mempunyai kandungan nutrisi dan bahan organiknya yang tinggi. Sehingga dapat meningkatkan kandungan karbon organik tanah, dapat meningkatan aktivitas mikroorganisme tanah yang menguntungkan, dan dapat meningkatkan ketersediaan nutrisi bagi tanaman dari tanah. Ketika diubah menjadi pupuk kompos, maka limbah kotoran sapi menjadi pupuk yang mempunyai tiga nutrisi yaitu nitrogen, fosfor, dan kalium. Limbah kotoran sapi yang mengandung urine mengandung 95\% yang bersumber dari air, $2,5 \%$ urea dan sisanya $2,5 \%$ merupakan dari campuran garam, hormon, enzim, dan mineral. Urine sapi ini juga berguna dapat membunuh bakteri, virus, dan jamur yang ada pada tanah dalam persawahan terhadap pestisida dan herbisida,

$$
\text { Lingkungan Hidup dan Bencana } \quad 560
$$


sehingga ramah lingkungan dan terhindar dari bahan pengawet.

Selain itu, limbah kotoran sapi juga dapat dimanfaatkan untuk berbagai macam kebutuhan, karena limbah tersebut masih terdapat kandungan nutrisi atau zat padat yang memiliki potensial jika dimanfaatkan. Limbah kotoran sapi ini memiliki banyak zat makanan seperti lemak, protein, Bahan Ekstrak Tanpa Nitrogen (BETN), mineral, vitamin, mikroba atau biota, dan zat-zat yang lain (unidentified subtances). Pemanfatan limbah ternak dapat mengurangi pencemaran yang diakibatkan oleh kegiatan usaha peternakan. Limbah kotoran sapi ini dapat dimanfaatkan menjadi pupuk organik ataupun pupuk kandang Adapun proses pengolahan pupuk organik dari limbah kotoran sapi ini, sebagai berikut: 1) Dibuat kotak tempat limbah kotoran sapi dengan cara membuat gorong-gorong yang memiliki penampang $1 \mathrm{~m}$ dan disusun sebanyak 3 buah. Selain itu, ada juga gorong-gorong sebanyak dua buah yang harus diletakkan di bawah permukaan yang mempunyai kedalaman $90 \mathrm{~cm}$ dan yang satunya ditumpuk di atas permukaan tanah dengan ketinggian $100 \mathrm{~cm}$. Hal tersebut, dilakukan agar kotoran sapi dapat ditampung sebanyak 3 ton.

Kemudian 2) Kotoran sapi yang sudah ada dapat dilakukan dengan cara pengadukan agar dapat tercampur secara merata dengan urine, feses dan sisa-sisa makanan sapi. Apabila sudah tercampur antara urine, feses dan sisa - sisa makanan sapi, maka kotoran limbah sapi dapat dimasukan ke dalam kotak yang ukurannya $2 \times 1 \mathrm{~m}$ sedalam $2 \mathrm{~m}$ secara merata agar cukup padat sampai penuh. 3) Setelah limbah kotoran sapi penuh di dalam kotak dengan ukuran $2 \mathrm{~m}$ x $1 \mathrm{~m}$ dengan kedalaman $2 \mathrm{~m}$, maka langkah selanjutnya adalah ditutup menggunakan tanah galian lubang setinggi $30 \mathrm{~cm}$ dan timbunan sebaiknya dibiarkan selama 3 bulan, namun dapat dipakukan penyesuaiam dengan waktu penggunaannya.

Tahap selanjutnya yaitu 4) Limbah kotoran sapi yang telah melewati proses perombakan, maka limbah kotoran sapi dapat menjadi pupuk kompos dan siap dibongkar. Kompos digunakan secara langsung ke lahan pertanian yang dapat dikeringkan di bawah sinar matahari pada waktu di pagi hari. 5)
Hasil pengeringan dari kotoran limbah sapi dapat dihancurkan agar tidak mengeras dan dapat disaring dengan ayakan sesuai dengan ukuran yang diinginkan oleh para petani. Hal ini bertujuan sebagai pupuk tanaman hias dan hasil ayakannya sekitar 2 sampai $3 \mathrm{~mm}$, sehingga dapat digunakan untuk rumput di lapangan golf dan ladang pertanian. (Adityawarman, 2015).

Melalui keberadaan program KKN PPM Universitas Islam Indonesia, mahasiswa dapat berperan aktif dalam pengolahan sampah, khususnya limbah kotoran sapi yang bertujuan agar dapat meningkatkan nilai perekonomian khususnya pemelihara sapi dan juga dapat meningkatkan kesadaran masyarakat terhadap pentingnya dalam menjaga lingkungan agar terhindar dari penyakitpenyakit yang disebabkan oleh pencemaran lingkungan, yaitu salah satunya dengan cara melakukan pengolahan limbah kotoran sapi ini menjadi pupuk organik.

Hal tersebut dikarenakan pemanfaatan limbah kotoran sapi masih belum dilakukan menjadi produk pupuk organik dengan nilai komersil. Kebanyakan warga hanya menumpuk kotoran sapi di samping kandang ataupun di belakangnya dan jika sudah masa panen padi ataupun bahan pangan lainnya, tinja tersebut dibuang ke sawah miliknya tanpa dilakukan pengolahan pupuk organik secara tepat. Cara tersebut merupakan cara yang paling sederhana yang sering dijumpai. Akan tetapi, cara pengolahan ini belum dapat disebut cara yang ramah dengan lingkungan, karena pengolahannya dilakukan dengan cara dikeringkan yang nantinya dapat menyebabkan pencemaran udara atau bau yang tidak sedap. Selain itu, dapat juga mengganggu kesehatan seperti pada pernapasan warga sekitar pemilik sapi apalagi di masa pandemi Covid-19 yang menuntut masyarakat supaya menjaga kesehatan terutama paru-paru.

Pelaksanaan dimulai dengan melakukan kegiatan pemetaan area seperti sosialisasi terhadap masyarakat yang dilaksanakan secara daring, implementasi pelaksanaan pengolahan limbah kotoran sapi, analisis evaluasi pembelajaran, dan peningkatan mutu pada limbah kotoran sapi. Pengolahan limbah kotoran sapi ini adalah salah satu

$$
\text { Lingkungan Hidup dan Bencana }
$$


cara untuk menanggulangi akibat naiknya harga pupuk anorganik, selain itu juga bisa menjadikan peningkatan nilai ekonomi bagi warga Desa Ringinputih itu sendiri sebagai pengolah kotoran sapi menjadi pupuk organik. Dari kegiatan ini, dihasilkan proses pengolahan tepat guna untuk pengolahan limbah kotoran sapi dengan membuat tempat penampung ukuran 2 x 1 meter dan kedalamannya 2 meter. Produk pupuk organik yang mampu menahan air lebih tinggi melalui proses pengomposan. Selain itu, diperoleh nilai tambah dalam dari segi aspek kesehatan karena hilangnya polusi dari kotoran sapi.

Video asinkron yang dibuat mahasiswa terkait dengan pemberdayaan masyarakat dijelaskan secara detail sebagai berikut:

Tabel 1. Storyboard pengolahan sampah organik

\begin{tabular}{cl}
\hline Time & \multicolumn{1}{c}{ Isi } \\
Frame & \\
\hline $00.00-$ & Pengenalan anggota kelompok dan \\
00.30 & program \\
$00.31-$ & Diskripsi program tujuan yang diharapkan, \\
01.00 & sasaran kegiatan \\
$01.01-$ & Penjelasan pengolahan limbah kotoran \\
02.00 & sapi menjadi pupuk organik \\
$02.01-$ & Penjelasan cara pembuatan pupuk organik \\
05.00 & \\
$05.01-$ & Penjelasan hasil program/produk ( \\
07.00 & ANIMASI ) \\
$07.01-$ & Kesimpulan \\
09.00 & Testimoni dari salah satu warga Desa \\
$09.01-$ & Ringinputih peternak sapi \\
\hline
\end{tabular}

Langkah selanjutnya, kelompok bidang pemberdayaan membuat naskah teks sesuai dengan storyboard atau pembagian waktunya dengan cara merekam suara, yang nantinya digunakan untuk dubbing suara dalam video bidang pemberdayaan ini. Namun, proses finalisasi naskah video ini membutuh diskusi lanjutan untuk menyatukan opini setiap orang yang berbeda-beda tersebut.

Pembuatan video tersebut dilakukan dengan cara, menjelaaskan isi materi video yang sesuai dengan storyboard terlebih dahulu kepada salah satu tokoh masyarakat dan dilanjutkan dengan wawancara khususnya cara warga dalam pengolahan kotoran sapi dan meminta testimoni atau tanggapan setelah mahasiswa menjelaskan materi tersebut.
Selain kotoran sapi, pemanfaatan limbah rumah tangga masih belum banyak dilakukan terutama oleh anak-anak Sekolah Dasar (SD). Kewajiban Belajar dari Rumah (BdR) di masa pandemi secara tidak langsung berontribusi dalam penimbunan timbulan sampah. Dikarenakan para siswa lebih banyak menghabiskan waktu mereka di rumah. Terlebih lagi, jika berhasil mendidik anakanak di sana, maka sampah organik tidak akan dibuang sia-sia lagi. Bahkan, dapat memiliki nilai guna dan nilai ekonomis yang lumayan tinggi. Di sisi lain, tujuan dari program ini yaitu mengedukasi siswa-siswi SD mengenai cara mengolah sampah organik menjadi pupuk kompos sehingga mereka mengetahui dasar-dasar cara membuat penyubur tanama tersebut.

Ditinjau dari hasil pengalaman dilokasi, ternyata ditemukan bahwa sebenarnya siswa-siswi SD sudah mengetahui jika sampah dapat dikelola menjadi keanekaragaman produk yang berguna. Namun, mereka tidak mengerti cara mengelola sampak organik tersebut dengan baik dan benar supaya memiliki nilai guna. Dari hasil kegiatan program ini, akhirnya mahasiswa mengetahui bahwasannya siswa-siswi SD bukanlah orang yang tertinggal, namun masyarakat yang kurang edukasi lebih lanjut mengenai hal-hal tertentu.

Sampah adalah suatu material sisa yang dihasilkan setelah berakhirnya suatu proses dan keberadaannya tidak diinginkan. Manusia mengartikan sampah berdasarkan derajat keterpakaiannya, sebenarnya tidak ada konsep sampah dalam proses-proses alam, yang ada hanya produk-produk yang dihasilkan setelah dan selama proses alam tersebut berlangsung. Sampah organik merupakan sampah yang bisa dikatakan lebih ramah lingkungan dibanding dengan sampah anorganik karena sifatnya yang mudah terurai oleh bakteri, namun sampah alami memiliki bahaya karena dapat menimbulkan bau busuk yang tidak sedap dan penyakit. Salah satu teknik pengolahan sampah organik yang paling mudah dilakukan adalah pembuatan pupuk kompos yaitu dengan cara mencampur sampah organik seperti dedaunan, kulit buah, dan kulit telur dengan tanah kemudian ditambahkan dengan tanah dan penghasil bakteri, pupuk kompos sendiri memiliki manfaat untuk menyuburkan tanaman. Proses pembuatan untuk Lingkungan Hidup dan Bencana 562 
pupuk kompos ini dapat dilakukan pada kondisi aerobik dan anaerobik. Pengomposan secara aerobik adalah proses dekomposisi bahan organik dengan bantuan oksigen (udara) yang memiliki produk utama dari metabolisme biologi aerobiknya yaitu air, karbondioksida, dan panas. Sedangkan pengomposan secara anaerobik yaitu proses dekomposisi bahan organik tanpa menggunakan oksigen dan produk akhir yang dihasilkan dari metabolisme anaerobik adalah karbondioksida, metana dan senyawa tertentu seperti asam organik. Namun pada dasarnya pupuk organik padat maupun cair dibuat dengan cara dekomposisi yang memanfaatkan aktivitas mikroba, sehingga kualitas kompos dan kecepatan dekomposisi tergantung pada keadaan serta jenis mikroba yang aktif selama proses pengomposan. pada proses pengomposan ini, kondisi optimum untuk aktivitas mikroba perlu diperhatikan, misalnya aerasi, sumber makanan bagi mikroba dan media tumbuh (Yuwono, 2006). Adapun faktorfaktor yang dapat mempengaruhi proses pembuatan pupuk organik tersebut adalah ukuran bahan, nilai $\mathrm{C} / \mathrm{N}$ bahan, campuran bahan, mikroorganisme yang bekerja, aerasi, kelembaban, keasaman $(\mathrm{pH})$, dan temperatur (Indriani, 2002).

Berdasarkan data Dinas Pekerjaan Umum Kabupaten Klaten tahun 2012, timbulan sampah yang dihasilkan di kabupaten yang di sisi barat berbatasan dengan Daerah Istimewa Yogyakarta tersebut adalah sebanyak $768 \mathrm{~m} 3 /$ hari. Jenis sampah yang dominan timbul adalah sampah organik (65\%) dan sampah plastik (10\%). Pengelolaan sampah padat di masyarakat selama ini berupa ditimbun atau dibakar di kebun dan sebagian lagi dibuang ke sungai (Dewi, Herawati, \& Ganefati, 2015). Sampah dengan jumlah sebesar itu akan memberikan dampak berupa banjir, pencemaran lingkungan, dan penyakit jika tidak diolah dengan baik.

Pemanfaatan limbah ini dapat dilakukan dengan menjadikannya hal baru yang lebih bermanfaat. Salah satu usahanya adalah dengan mengubahnya menjadi pupuk kompos. Pembuatan kompos bisa dilakukan dengan bahan sampah taman. Proses pengomposan dapat berjalan dengan lebih cepat dan efisien dengan menambahkan mikroorganisme perombak bahan organi. Venny Arnika salah satu orang yang memanfaatkan aktivator Effective Microorganism EM-4 dalam proses pembuatan pupuk organik dengan bahan tandan kosong kelapa sawit sisa media jamur merang (Volvariella volvacea) (Sahil, Henie, Al, Rohman, \& Syamsuri, 2016). Selain itu, EM-4 juga dapat digunakan untuk memperbaiki struktur dan tekstur tanah menjadi lebih baik serta dapat pasokan unsur hara yang dibutuhkan oleh tanaman. Sehingga penggunaan EM-4 dapat membuat tanaman menjadi lebih sehat, subur, dan relatif tahan pada penyakit dan serangan hama. Adapun manfaat-manfaat EM-4 bagi tanaman dan tanah antara lain: 1) Menunjang dalam meningkatkan daya tampung fotosintesis tanaman; 2) Dapat meningkatkan kualitas bahan organik yang dapat digunakan sebagai pupuk; 3) Dapat meningkatkan kualitas pertumbuhan vegetatif dan regeneratif tanaman; 4) Menghambat penyakit pada tanaman di dalam tanah dan pertumbuhan hama.

\section{KESIMPULAN}

Hasil dari kegiatan pengabdian masyarakat berupa KKN PPM ini berupa cara pengolahan dan pemanfaatan sampah organik di rumah tangga menjadi kompos. Selain itu, kompos yang dihasilkan harapannya dapat digunakan oleh masyarakat sebagai media tanam sayuran di rumah, sehingga masyarakat bisa mengkonsumsi sayuran organik yang ditanam sendiri. Kompos dan sayuran tersebut dijadikan komoditas dagang oleh masyarakat, begitu juga keberadaan sayur-mayur hasil tanam sendiri dapat menghemat pengeluaran terutama di masa wabah Covid-19.

\section{UCAPAN TERIMA KASIH}

Kegiatan pengabdian masyarakat ini bisa terlaksana dengan lancar berkat bantuan dari Direktorat Riset dan Pengabdian Masyarakat, Deputi Bidang Penguatan Riset dan Pengembangan, Kementerian Riset dan Teknologi/Badan Riset dan Inovasi Nasional sesuai dengan Kontrak 1 Nomor: 102/SP2H/PPM/DRPM/2020, Tanggal 12 Februari 2020. Didukung oleh Direktorat Penelitian dan Pengabdian Masyarakat UII. Ucapan terima kasih disampaikan kepada kedua pihak tersebut.

\section{REFERENSI}

Lingkungan Hidup dan Bencana 
Abduh, M. N. (2018). Ilmu Dan Rekayasa Lingkungan. Makassar: CV Sah Media.

Adityawarman, A.C. (2015). Pengolahan Limbah Ternak Sapi Secara Sederhana di Desa Pattalassang Kabupaten Sinjai Sulawesi Selatan. Jurnal Ilmu Produksi dan Teknologi Hasil Peternakan 3, 7.

Anonim. (2008). Undang-Undang Nomor 18 Tahun 2008 tentang Pengelolaan Sampah. Sekretariat Negara Republik Indonesia, Jakarta.Undang-Undang Republik Indonesia No. 18 Tahun 2008 Tentang Pengelolaan Sampah.

Damanhuri, E., Padmi, T. (2010). Diktat Kuliah TL-3104 Pengelolaan Sampah. Institut Teknologi Bandung.

Dewi, S. P., Herawati, L., \& Ganefati, S. P. (2015). Pengaruh Penyuluhan Dengan Metoda Demonstrasi Terhadap Dan Tindakan Pengelolaan Sampah Ibu-Ibu di Desa Cetan, Kecamatan Ceper, Kabupaten Klaten, 6(3).

Iskandar, A.A. (2018). Pentingnya Memelihara Kebersihan dan Keamanan Lingkungan Secarapartisipatif Demi Meningkatkan Gotong Royong dan Kualitas Hidup Warga 6.

Kementrian Lingkungan Hidup RI. (2011). Bank Sampah dan 3R : Membangun Lingkungan dan Ekonomi Kerakyatan.

Mulyatun. (2016). Sumber Energi Terbarukan dan Pupuk Organik dari Limbah Kotoran Sapi, DIMAS - Volume 16, Nomor 1, Mei, pp. 191214.

Sahil, J., Henie, M., Al, I., Rohman, F., \& Syamsuri, I. (2016). Sistem Pengelolaan Dan Upaya
Penanggulangan Sampah di Kelurahan Dufa- Dufa Kota Ternate.

Suryati, T. (2014). Bebas Sampah Dari Rumah. Jakarta: AgroMedia Pustaka.

Wijayanti, Y., Widyastari, H. (2018). Dasa Wisma Bebas Penyakit Berbasis Lingkungan Melalui Home Environmental Health And Safety. HIGEIA 2 , 171-180. 